\title{
Lipids and nitrogen isotopes of two deep-water corals from the North-East Atlantic: initial results and implications for their nutrition
}

\author{
Kostas Kiriakoulakis ${ }^{1}$, Elizabeth Fisher ${ }^{1}$, George A. Wolff ${ }^{1}$, André Freiwald ${ }^{2}$, \\ Anthony Grehan ${ }^{3}$, J. Murray Roberts ${ }^{4}$ \\ ${ }^{1}$ Department of Earth and Ocean Sciences, University of Liverpool, 4 Brownlow \\ Street, Liverpool, L69 3GP, UK \\ (kos@liverpool.ac.uk) \\ ${ }^{2}$ Institute of Paleontology, Erlangen University, Loewenichstr. 28, D-91054 \\ Erlangen, Germany \\ ${ }^{3}$ Martin Ryan Marine Science Institute, National University of Ireland, Galway, \\ Ireland \\ ${ }^{4}$ Scottish Association for Marine Science, Dunstaffnage Marine Laboratory, Oban, \\ Argyll, PA37 1QA, UK
}

\begin{abstract}
The lipid and organic nitrogen isotopic $\left(\delta^{15} \mathrm{~N}\right)$ compositions of two common deep-water corals (Lophelia pertusa and Madrepora oculata) collected from selected locations of the NE Atlantic are compared to the composition of suspended particulate organic matter, in order to determine their principle food source. Initial results suggest that they may feed primarily on zooplankton. This is based on the increased abundances of mono-unsaturated fatty acids and alcohols and the different ratios of the polyunsaturated fatty acids, 22:6/20:5 of the corals when compared to those of the suspended particulate organic matter. There is enrichment in L. pertusa of mono-unsaturated fatty acids and of $\delta^{15} \mathrm{~N}$ relative to M. oculata. It is unclear whether this reflects different feeding strategies or assimilation/storage efficiencies of zooplankton tissue or different metabolism in the two coral species.
\end{abstract}

Keywords. Deep-water corals, suspended particulate organic matter, nitrogen isotopes, lipids, fatty acids, PUFA, MUFA

\section{Introduction}

Cold-water azooxanthellate corals (most commonly Lophelia pertusa and Madrepora oculata) are widespread at the western European continental margin, where their framework and structure support diverse ecosystems (e.g., Freiwald et al. 2002). The deep-water corals (DWCs) often grow on carbonate mounds (e.g., Hovland et al. 1994; Henriet et al. 1998; Freiwald et al. 1999, 2002; De Mol et al. 2002; Huvenne et al. 2002 amongst others). They normally occur between 50 and

Freiwald A, Roberts JM (eds), 2005, Cold-water Corals and Ecosystems. Springer-Verlag Berlin Heidelberg, pp 715-729 
$2000 \mathrm{~m}$ depth, typically at temperatures of $4-12^{\circ} \mathrm{C}$ (Wilson 1979 ; Kenyon et al. 1998, 2003; Rogers 1999; De Mol et al. 2002, 2005), although they can tolerate sub-zero water temperatures for short periods of time (Bett 2000). L. pertusa, the dominant DWC, sometimes forms extensive reefs (e.g., Sula Ridge - Norwegian Shelf; Freiwald et al. 1999, 2002), but more often occurs as small colonies of a few centimetres to a few metres across (e.g., Darwin Mounds - Northern Rockall Trough; Masson et al. 2003).

Despite their widespread distribution, very little is known regarding the nutrition of DWCs and their role in the biogeochemistry of carbon and nitrogen. Observations of corals in aquaria and in situ provide evidence that $L$. pertusa can selectively feed on live zooplankton of up to $2 \mathrm{~cm}$, although it also ingests sediment particles (Mortensen 2001; Freiwald 2002). It has also been suggested that DWCs may acquire their nutrients from bacteria associated with seafloor hydrocarbon seeps, which in turn promote carbonate mound formation (Hovland and Thomsen 1997; Henriet et al. 1998). However, coral-colonised mounds occur in areas where such seeps are absent and it seems that ambient current strength, the availability of hard substrata and elevated locations are key factors influencing the distributions of DWCs (Rogers 1999; Masson et al. 2003; van Rooij et al. 2003; Kiriakoulakis et al. 2004).

The principal objective of this study was to assess the preferred food source of the DWCs. Our approach was to investigate the biochemical (lipid) and isotopic $\left(\delta^{15} \mathrm{~N}\right)$ compositions of the two most common species in the NW European margin, $L$. pertusa and $M$. oculata and to compare these with suspended particulate organic matter (sPOM) in overlying waters. Lipids are essential in the storage and mobilisation of energy, in reproduction and metabolism and are key components in cell membranes (e.g., Brassell and Eglinton 1986). The distributions of fatty acids can be used to determine the diet of biogenic material of marine organisms (e.g., Parrish et al. 2000). To date, there have been few studies of lipids in DWCs (e.g., Mancini et al. 1999), in contrast to their shallow-water counterparts (e.g., Meyers 1979; Latyshev et al. 1991; Harland et al. 1993; Yamashiro et al. 1999 amongst others).

The stable isotopes of nitrogen $\left({ }^{15} \mathrm{~N} /{ }^{14} \mathrm{~N}\right)$ also have value in ecosystem studies (Owens 1987; Peterson and Fry 1987; Hesslein et al. 1991; Kling et al. 1992; Kidd et al. 1995), although their application to deep-water settings has been limited (e.g., Iken et al. 2001; Heikoop et al. 2002a, b).

\section{Sampling}

Lophelia pertusa and Madrepora oculata samples were obtained from selected sites along the western European margin $(n=11,3$ respectively Fig. 1$)$ between the years 1998-2000 (Table 1). Samples were collected from a wide range of depths (Table 1) using a variety of gear (boxcores, grabs, dredges, trawls and remotely operated vehicle (ROV)). When possible, sPOM was collected by in situ filtration of large volume ( 1000 l) water samples from the same locations (Darwin, Logachev, 


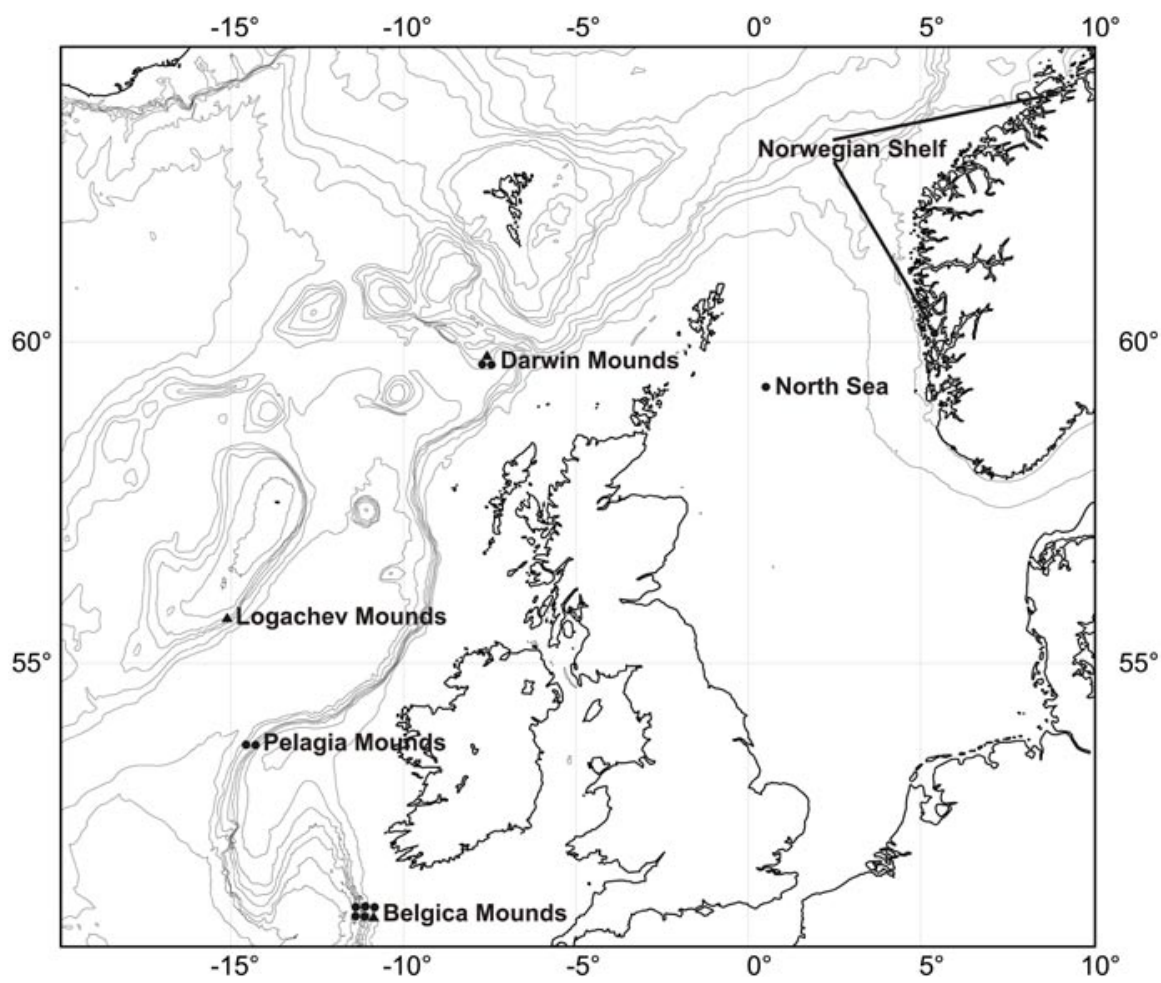

Fig. 1 Bathymetric map of the locations sampled for corals. Contours are every $200 \mathrm{~m}$ down to $1000 \mathrm{~m}$, every $500 \mathrm{~m}$ down to $2000 \mathrm{~m}$ and every $1000 \mathrm{~m}$ down to $4000 \mathrm{~m}$. Black circles denote Lophelia pertusa and triangles Madrepora oculata

Hovland and Belgica Mounds only; Table 2; $293 \mathrm{~mm} \mathrm{GF} / \mathrm{F}$; stand alone pumping system - Challenger Oceanic; Kiriakoulakis et al. 2004). In all cases the coral and filter samples were immediately frozen $\left(-20^{\circ} \mathrm{C}\right)$ and then freeze-dried before analysis.

\section{Methodology}

Methods for analysis of lipids have been described in detail elsewhere (Kiriakoulakis et al. 2001). No separation of lipid classes (e.g., phospholipids, glycolipids, etc.) was attempted.

Briefly, separate aliquots of freeze-dried filter and coral tissue material (0.5$1 \mathrm{~g}$ ) were spiked with internal standard (cholestane), Soxhlet extracted (24 h; dichloromethane:methanol 9:1) and methylated (methanolic acetyl chloride; Christie 1982). GC-MS analyses were carried out on the silylated (bis-trimethyl silyltrifluoroacetamide; BSFTA, $1 \%$ TMS; $30-50 \mu \mathrm{l} ; 40^{\circ} \mathrm{C} ; 0.5-1 \mathrm{~h}$ ), methylated total extracts using a Trace 2000 Series gas chromatograph (on-column injector; fused silica high temperature column, $60 \mathrm{~m} \times 0.25 \mathrm{~mm}$ i.d.; $0.1 \mu \mathrm{m}$ film thickness, 


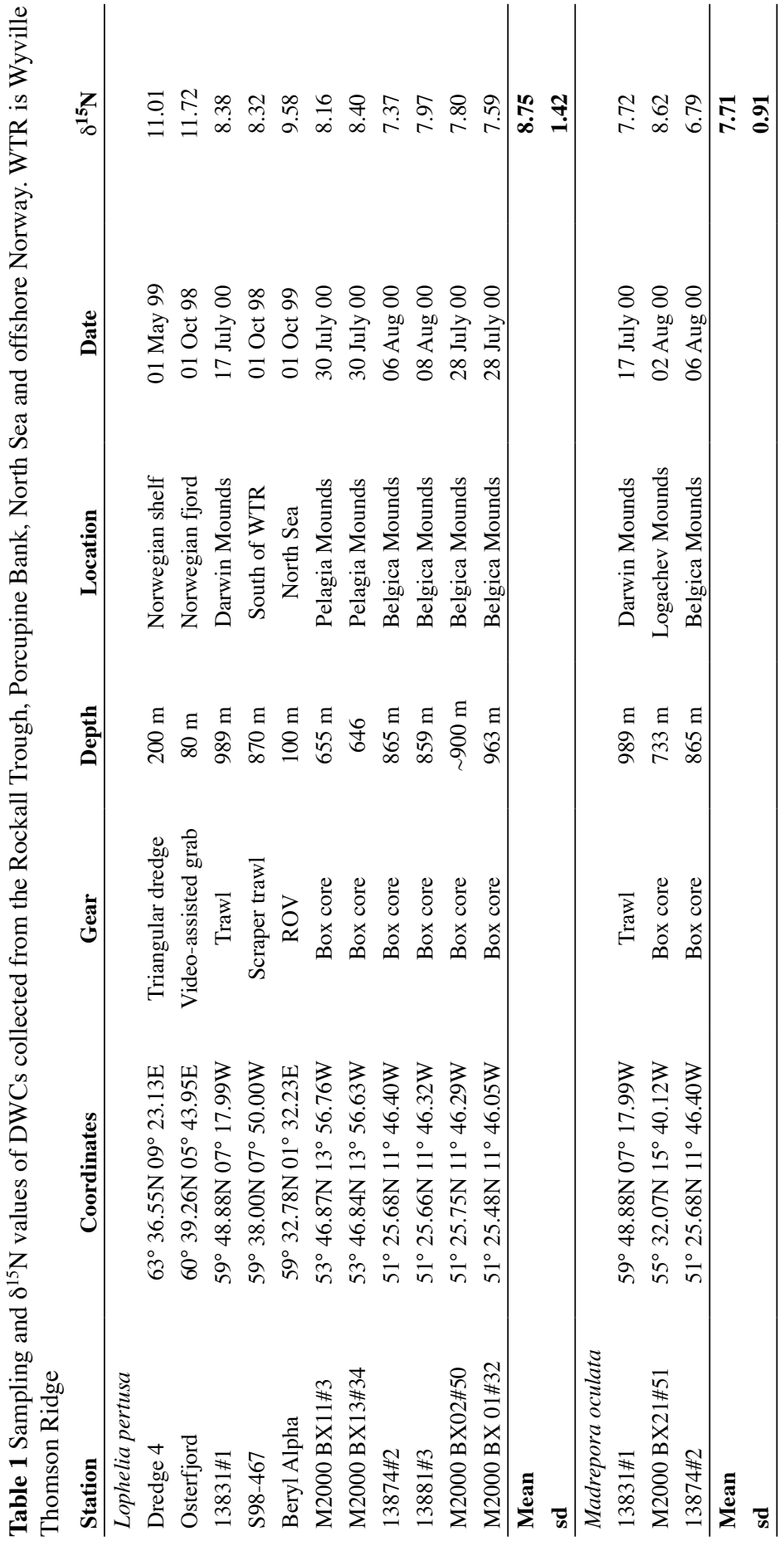


Table 2 Sampling and $\delta^{15} \mathrm{~N}$ values for sPOM collected from the Rockall Trough and Porcupine Bank. In most cases sPOM was collected from 10-30 m above bottom, i.e., at or close to the benthic boundary layer (BBL). *Water collected at $150 \mathrm{~m}$ above bottom (mab)

\begin{tabular}{|c|c|c|c|c|}
\hline Station & Location & Date & Depth & $\delta^{15} \mathbf{N}$ \\
\hline $13823 \# 12 *$ & Darwin Mounds & 14-Jul-00 & $943 \mathrm{~m}$ & 5.37 \\
\hline $13825 \# 1 *$ & Darwin Mounds & 15-Jul-00 & $948 \mathrm{~m}$ & 5.09 \\
\hline $13828 \# 1 *$ & Darwin Mounds & 16-Jul-00 & $938 \mathrm{~m}$ & 3.03 \\
\hline $13832 \# 2 *$ & Darwin Mounds & 17-Jul-00 & $938 \mathrm{~m}$ & 5.02 \\
\hline $13841 \# 1 *$ & Darwin Mounds & 19-Jul-00 & $948 \mathrm{~m}$ & 6.27 \\
\hline $13823 \# 8$ & Darwin Mounds & 14-Jul-00 & & 5.98 \\
\hline $13823 \# 12$ & Darwin Mounds & 14-Jul-00 & $943 \mathrm{~m}$ & 5.78 \\
\hline $13825 \# 1$ & Darwin Mounds & 15-Jul-00 & $948 \mathrm{~m}$ & 4.75 \\
\hline 13828\#1 & Darwin Mounds & 16-Jul-00 & $938 \mathrm{~m}$ & 5.53 \\
\hline $13832 \# 2$ & Darwin Mounds & 17-Jul-00 & $938 \mathrm{~m}$ & 5.73 \\
\hline 13841\#1 & Darwin Mounds & 19-Jul-00 & $948 \mathrm{~m}$ & 4.91 \\
\hline SAPS4 & Logachev Mounds & 12-Aug-01 & $666 \mathrm{~m}$ & \\
\hline GeoB 8029/1 & Logachev Mounds & 23-Jul-02 & $700 \mathrm{~m}$ & \\
\hline GeoB 8036/1 & Logachev Mounds & 24-Jul-02 & $700-730 \mathrm{~m}$ & \\
\hline SAPS3 & Pelagia Mounds & 9-Aug-01 & $635 \mathrm{~m}$ & \\
\hline GeoB 8050/1 & Porcupine Bank & 27-Jul-02 & $153 \mathrm{~m}$ & \\
\hline GeoB 6710 & Hovland Mounds & 17-Sep-00 & $691 \mathrm{~m}$ & \\
\hline GeoB 6713 & Hovland Mounds & 18-Sep-00 & $670 \mathrm{~m}$ & \\
\hline GeoB 6732/1 & Hovland Mounds & 24-Sep-00 & $700 \mathrm{~m}$ & \\
\hline GeoB 8042/1 & Hovland Mounds & 25-Jul-02 & $710 \mathrm{~m}$ & \\
\hline GeoB 8076/1 & Hovland Mounds & 29-Jul-02 & $850 \mathrm{~m}$ & \\
\hline GeoB 8048/1 & Hovland Mounds & 26-Jul-02 & $875 \mathrm{~m}$ & \\
\hline GeoB 8068/1 & Hovland Mounds & 29-Jul-02 & $655-700 \mathrm{~m}$ & 5.08 \\
\hline GeoB 8044/1 & Hovland Mounds & 26-Jul-02 & $805 \mathrm{~m}$ & \\
\hline GeoB 8078/1 & Hovland Mounds & 30-Jul-02 & $735-740 m$ & 4.67 \\
\hline SAPS2 & Hovland Mounds & 6-Aug-01 & $605 \mathrm{~m}$ & \\
\hline GeoB 8081/1 & Belgica Mounds & 31-Jul-02 & $916 \mathrm{~m}$ & 4.48 \\
\hline GeoB 8103/1 & Belgica Mounds & 2-Aug-02 & $680 \mathrm{~m}$ & 4.25 \\
\hline GeoB 8106/1 & Belgica Mounds & 2-Aug-02 & $880 \mathrm{~m}$ & 4.31 \\
\hline GeoB 6742/1 & Belgica Mounds & 26-Sep-00 & $830 \mathrm{~m}$ & \\
\hline SAPS1 & Belgica Mounds & 1-Aug-01 & $865 \mathrm{~m}$ & 7.33 \\
\hline GeoB 8107/1 & Belgica Mounds & 3-Aug-02 & $785-800 \mathrm{~m}$ & 4.16 \\
\hline
\end{tabular}

$5 \%$ phenyl/95 \% methyl polysiloxane equivalent phase, DB5-HT, J\&W; carrier gas helium at $1.6 \mathrm{ml} \mathrm{min}^{-1}$ ), coupled with a Thermoquest Finnigan TSQ7000 mass spectrometer (ionisation potential $70 \mathrm{eV}$; source temperature $215^{\circ} \mathrm{C}$; trap current $300 \mu \mathrm{A})$ and processed using Xcalibur software. Compounds were identified using authentic standards or relative retention indices, and quantified using cholestane as an internal standard (Kiriakoulakis et al. 2004).

Nitrogen isotopic analyses were carried out on aliquots of sPOM using a PDZ Europa Scientific Geo 20/20 running in continuous flow mode coupled to a Carlo- 
Erba Instruments EA1108 elemental analyser. Data were calibrated to atmospheric nitrogen by replicate analyses of the international standards NBS18, NBS19 and IAEACO1 as well as in-house nylon and alanine standards.

\section{Results}

\section{Suspended POM}

$\delta^{15} \mathrm{~N}$ of particulate organic nitrogen in selected samples collected at three sites (Darwin, Hovland and Belgica Mounds) ranged from +3.03 to $+7.33 \%$ (mean $5.01 \pm 0.92 \%$ ) and were not significantly different between sites and/or depths (Table 2). One sample from the Belgica Mounds collected in summer 2001 (SAPS1) was heavier $(+7.33 \%$ ) than those collected a year later $(+4.16$ to $+4.68 \%$; Table 2). There are no sPOM data from the North Sea and Norwegian fjord and shelf. Detailed lipid results for sPOM are presented elsewhere (Kiriakoulakis et al. 2004, submitted), but to allow easy comparison with the coral lipids, the lipid compositions of POM from four sites (i.e., Darwin, Logachev, Hovland and Belgica Mounds) are presented in Table 3. They show significant regional differences in their distributions, but fatty acids and sterols dominate (mean for all sites $67.6 \pm$ $19.5 \%$ and $24.3 \pm 16.6 \%$, respectively; see Table 3 ), whereas alcohols are less abundant constituents of the POM (mean of all sites $6.5 \% \pm 3.9 \%$ ). Polyunsaturated fatty acids (PUFAs) comprise $20 \%( \pm 13.7 \%)$ of fatty acids and are dominated by $\mathrm{C}_{20: 4}, \mathrm{C}_{20: 5}$ and $\mathrm{C}_{22: 6}$ compounds with lesser amounts of $\mathrm{C}_{18: 4}$ at all sites. Bacterial fatty acids which include $\mathrm{C}_{15}, \mathrm{C}_{17}$, all branched and $\mathrm{C}_{18: 1} \Delta-7$ fatty acids are also abundant (mean $\sim 14 \pm 4.14 \%$ ), while the mono-unsaturated fatty acids (MUFAs), $\mathrm{C}_{20: 1}$ and $\mathrm{C}_{22: 1}$ fatty acids comprise $3 \pm 3.8 \%$ of fatty acids.

\section{Corals}

The $\delta^{15} \mathrm{~N}$ composition of $L$. pertusa tissue is variable, but this seems to be siterelated. Corals from the Belgica Mounds (4) have rather constant composition (mean $7.68 \pm 0.3 \%$ ) and this is also true for the two samples from the Pelagia Mounds site (mean $8.28 \%$ ) and the Northern Rockall Trough (i.e., Darwin Mounds and south of the Wyville Thomson Ridge, see Table 1). There are no seasonal or interannual data for the Pelagia and Belgica Mounds, but samples from the Northern Rockall Trough that were collected in 1998 and 2000 (Table 1) have similar isotopic values. The sample of L. pertusa from the North Sea is $\sim 1.3-1.8 \%$ o heavier, whereas samples from Norwegian waters are significantly heavier than all other samples (Table 1).

The $\delta^{15} \mathrm{~N}$ composition of $M$. oculata tissue from three sites is also variable (up to $\sim 2 \%$, Table 1). When comparing the isotopic composition of species collected from the same site L. pertusa seems consistently enriched in ${ }^{15} \mathrm{~N}$ (up to $1.2 \%$ at Belgica Mounds, Table 1) relative to $M$. oculata.

Lipids in L. pertusa are dominated by fatty acids (mean of all sites $67 \pm 7.8 \%$ ) and alcohols (mean of all sites $28.8 \pm 9.1 \%$ ). Sterol abundances are much lower $(4.2$ $\pm 4.3 \%$ ). Fatty acids and alcohols also dominate the lipids of M. oculata, with lower proportions of sterols (Table 4). The two species have significantly different PUFA/ 
Table 3 Lipid composition of sPOM at selected sites. *Water was collected $150 \mathrm{~m}$ above bottom (mab). ${ }^{1}$ relative to total lipids, ${ }^{2}$ relative to total fatty acids. FA is fatty acids, PUFAs, MUFAs and BactFA are poly-unsaturated, mono-unsaturated and bacterial fatty acids respectively. 22:6/20:5 is the ratio of the concentration of $\mathrm{C}_{22: 6} v s . \mathrm{C}_{20: 5}$ PUFAs

\begin{tabular}{|c|c|c|c|c|c|c|c|c|}
\hline Station & $\begin{array}{l}\text { FA } \\
1 \%\end{array}$ & $\begin{array}{c}\text { alcohols } \\
1 \%\end{array}$ & $\begin{array}{c}\text { sterols } \\
1 \%\end{array}$ & $\begin{array}{c}\text { PUFAs } \\
2 \%\end{array}$ & $\begin{array}{c}\text { MUFAs } \\
2 \%\end{array}$ & $\begin{array}{c}\text { bactFA } \\
2 \%\end{array}$ & $22: 6 / 20: 5$ & $\begin{array}{l}\text { PUFAs/ } \\
\text { MUFAs }\end{array}$ \\
\hline $13823 \# 12^{*}$ & 88.99 & 1.98 & 8.97 & 22.37 & 0.00 & 19.20 & 1.03 & \\
\hline $13825 \# 1 *$ & 77.75 & 10.03 & 11.55 & 46.38 & 13.87 & 10.52 & 6.49 & 68.10 \\
\hline $13828 \# 1 *$ & 21.40 & 12.81 & 65.70 & 11.23 & 2.06 & 9.51 & 0.55 & 5.46 \\
\hline $13832 \# 2 *$ & 85.97 & 4.74 & 9.10 & 37.70 & 14.11 & 12.24 & 1.33 & 16.60 \\
\hline $13841 \# 1 *$ & 92.49 & 1.21 & 5.63 & 41.63 & 13.66 & 13.35 & 1.18 & 23.00 \\
\hline $13823 \# 8$ & 70.65 & 2.99 & 26.01 & 28.19 & 1.69 & 11.27 & 1.14 & 16.73 \\
\hline $13823 \# 12$ & 86.88 & 10.02 & 3.07 & 29.60 & 2.93 & 11.29 & 0.69 & 10.11 \\
\hline $13825 \# 1$ & 92.00 & 2.39 & 5.49 & 29.94 & 1.12 & 19.47 & 1.11 & 60.13 \\
\hline $13828 \# 1$ & 90.75 & 2.90 & 6.11 & 41.51 & 2.17 & 11.24 & 1.37 & 19.14 \\
\hline $13832 \# 2$ & 90.72 & 2.28 & 6.85 & 22.70 & 1.50 & 20.27 & 0.80 & 15.11 \\
\hline $13841 \# 1$ & 86.43 & 9.10 & 4.40 & 37.56 & 3.03 & 17.40 & 1.16 & 162.23 \\
\hline mean Darwin & 89.36 & 5.34 & 5.18 & 32.26 & 2.15 & 15.93 & 1.03 & 53.34 \\
\hline sd ( \pm ) & 2.52 & 3.88 & 1.48 & 7.37 & 0.84 & 4.39 & 0.28 & 64.03 \\
\hline SAPS4 & 30.69 & 16.43 & 46.56 & 16.32 & 0.00 & 5.40 & & \\
\hline GeoB8029/1 & 64.43 & 2.19 & 27.00 & 23.80 & 0.00 & 10.52 & 1.32 & \\
\hline GeoB8036/1 & 75.71 & 6.40 & 17.59 & 7.39 & 0.32 & 12.44 & 1.41 & 23.36 \\
\hline mean Logachev & 56.94 & 8.34 & 30.38 & 15.84 & 0.11 & 9.45 & 0.91 & 23.36 \\
\hline $\operatorname{sd}( \pm)$ & 23.43 & 7.31 & 14.78 & 8.22 & 0.18 & 3.64 & 0.79 & \\
\hline GeoB 6710 & 53.38 & 4.54 & 41.07 & 7.85 & 0.73 & 19.11 & 3.40 & 10.75 \\
\hline GeoB 6713 & 56.09 & 5.79 & 31.14 & 0.00 & 0.00 & 12.89 & & \\
\hline GeoB 6732/1 & 52.59 & 4.96 & 38.65 & 4.42 & 1.18 & 16.72 & & 3.75 \\
\hline GeoB 8042/1 & 71.32 & 4.05 & 23.85 & 22.22 & 1.01 & 13.66 & & 0.64 \\
\hline GeoB 8076/1 & 79.32 & 3.19 & 17.49 & 25.49 & 4.37 & 15.04 & 1.50 & 5.83 \\
\hline GeoB 8048/1 & 65.43 & 5.37 & 29.20 & 18.79 & 2.99 & 14.06 & 1.10 & 6.28 \\
\hline GeoB 8068/1 & 73.87 & 12.11 & 14.02 & 38.21 & 2.34 & 9.74 & 1.90 & 16.30 \\
\hline GeoB 8044/1 & 80.07 & 10.48 & 9.36 & 3.15 & 1.65 & 18.75 & 0.61 & 1.90 \\
\hline GeoB 8078/1 & 67.65 & 7.49 & 23.69 & 3.42 & 1.20 & 20.50 & & 2.85 \\
\hline SAPS2 & 31.89 & 7.50 & 60.61 & 0.00 & 0.00 & 22.68 & & \\
\hline mean Hovland & 63.16 & 6.55 & 28.91 & 12.35 & 1.55 & 16.32 & 1.70 & 6.04 \\
\hline sd ( \pm ) & 14.87 & 2.87 & 15.06 & 13.05 & 1.36 & 3.95 & 1.06 & 5.20 \\
\hline GeoB 8081/1 & 59.64 & 4.47 & 35.89 & 31.58 & 2.50 & 9.98 & 1.46 & \\
\hline GeoB 8103/1 & 52.42 & 9.22 & 37.60 & 21.70 & 1.92 & 8.25 & 1.39 & 11.30 \\
\hline GeoB 8106/1 & 64.05 & 5.84 & 28.70 & 17.78 & 1.97 & 15.97 & 1.45 & 9.04 \\
\hline GeoB 6742/1 & 52.26 & 4.05 & 27.89 & 2.45 & 4.12 & 18.26 & & 0.59 \\
\hline SAPS1 & 31.86 & 14.78 & 51.13 & 4.41 & 1.24 & 16.09 & & 3.56 \\
\hline GeoB 8107/1 & 61.83 & 8.31 & 29.86 & 7.19 & 0.00 & 15.07 & 0.18 & \\
\hline Mean Belgica & 53.68 & 7.78 & 35.18 & 14.19 & 1.96 & 13.94 & 1.12 & 6.12 \\
\hline sd ( $( \pm)$ & 11.74 & 4.00 & 8.76 & 11.44 & 1.37 & 3.92 & 0.63 & 4.91 \\
\hline mean total & 67.60 & 6.50 & 24.28 & 20.10 & 2.70 & 14.22 & 1.46 & 20.86 \\
\hline
\end{tabular}


MUFA ratios (ANOVA; $\mathrm{p}<0.05$ ); in $M$. oculata this ratio is three times higher than in L. pertusa. The proportions of bacterial fatty acids and the 22:6/20:5 ratio are similar in both species (Table 4 ). $\mathrm{C}_{20: 1}$ and $\mathrm{C}_{22: 1}$ alcohols constitute $>90 \%$ of total alcohols in both species.

Mean lipid compositions of both coral species are also significantly different (ANOVA; $<20.05$ ) to those of the sPOM at all sites (Tables 3 and 4). In particular, mean fatty alcohol and MUFA proportions are significantly higher in the DWCs $(26.1 \pm 10.2 \%$ and $19.7 \pm 10.4 \%$, respectively) than in the $\operatorname{sPOM}(6.5 \pm 3.9 \%$ and $2.7 \pm 3.8 \%$, respectively), whereas the reverse is true for sterols $(4.5 \pm 4 \%$ for the corals and $24.3 \pm 16.6 \%$ for $\mathrm{sPOM})$ and bacterial fatty acids $(5.6 \pm 1.5 \%$ for the corals and $14.2 \pm 4.1 \%$ for sPOM). On the other hand, total fatty acids and PUFAs are not significantly different between the corals $(69.5 \pm 8.7 \%$ and $25.8 \pm 11.1 \%$ respectively) and $\operatorname{sPOM}(67.6 \pm 19.5 \%$ and $20.1 \pm 13.7 \%$ respectively $)$. Mean 22:6/20:5 ratios do however differ between the corals $(0.6 \pm 0.1)$ and sPOM (1.5 \pm 1.2 ).

Table 4 Lipid composition of collected coral samples. ${ }^{1}$ relative to lipids, ${ }^{2}$ relative to total fatty acids. FA is fatty acids, PUFAs, MUFAs and BactFA are poly-unsaturated, mono-unsaturated and bacterial fatty acids respectively. $22: 6 / 20: 5$ is the ratio of the concentration of $\mathrm{C}_{22: 6} v s$. $\mathrm{C}_{20: 5}$ PUFAs

\begin{tabular}{|c|c|c|c|c|c|c|c|c|}
\hline Station & $\begin{array}{l}\text { FA } \\
1 \%\end{array}$ & $\begin{array}{c}\text { alcohols } \\
1 \%\end{array}$ & $\begin{array}{c}\text { sterols } \\
1 \%\end{array}$ & $\begin{array}{c}\text { PUFAs } \\
2 \%\end{array}$ & $\begin{array}{c}\text { MUFAs } \\
2 \%\end{array}$ & $\begin{array}{c}\text { bactFA } \% \\
2 \%\end{array}$ & 22:6/20:5 & $\begin{array}{l}\text { PUFA/ } \\
\text { MUFA }\end{array}$ \\
\hline \multicolumn{9}{|l|}{ Lophelia pertusa } \\
\hline Dredge 4 & 64.07 & 35.30 & 0.63 & 21.56 & 38.44 & 4.95 & 0.61 & 0.56 \\
\hline Osterfjord & 69.61 & 28.19 & 2.20 & 23.37 & 12.18 & 5.92 & 0.67 & 1.92 \\
\hline 13831\#1 & 62.41 & 31.41 & 6.18 & 24.60 & 28.32 & 5.95 & 0.30 & 0.87 \\
\hline S98-467 & 77.56 & 21.32 & 1.11 & 24.80 & 28.10 & 5.59 & 0.52 & 0.88 \\
\hline Beryl Alpha & 63.07 & 36.62 & 0.31 & 27.78 & 31.46 & 4.03 & 0.68 & 0.88 \\
\hline M2000 BX11\#3 & 64.48 & 23.08 & 12.44 & 9.63 & 12.27 & 8.02 & 0.44 & 0.78 \\
\hline $13874 \# 2$ & 53.72 & 45.06 & 1.22 & 10.17 & 9.34 & 5.45 & 0.76 & 1.09 \\
\hline $13881 \# 3$ & 78.47 & 16.61 & 4.91 & 16.33 & 28.47 & 6.81 & 0.69 & 0.57 \\
\hline M2000 BX02\#50 & 69.07 & 21.89 & 9.04 & 31.49 & 12.23 & 5.26 & 0.74 & 2.57 \\
\hline Mean Lophelia & 66.94 & 28.83 & 4.23 & 21.08 & 22.31 & 5.77 & 0.60 & 1.13 \\
\hline sd ( $( \pm)$ & 7.76 & 9.08 & 4.27 & 7.56 & 10.75 & 1.13 & 0.15 & 0.68 \\
\hline \multicolumn{9}{|l|}{ Madrepora oculata } \\
\hline $13831 \# 1$ & 68.33 & 27.12 & 4.55 & 27.28 & 16.40 & 7.31 & 0.46 & 1.66 \\
\hline M2000 BX21\#51 & 84.19 & 6.79 & 9.01 & 45.97 & 8.53 & 5.63 & 0.61 & 5.39 \\
\hline $13874 \# 2$ & 78.69 & 19.41 & 1.90 & 42.69 & 11.10 & 2.41 & 0.66 & 3.85 \\
\hline Mean Madrepora & 77.07 & 17.78 & 5.15 & 38.65 & 12.01 & 5.12 & 0.58 & 3.63 \\
\hline sd ( $( \pm)$ & 8.05 & 10.26 & 3.60 & 9.98 & 4.01 & 2.49 & 0.10 & 1.87 \\
\hline Mean both species & 69.47 & 26.07 & 4.46 & 25.47 & 19.74 & 5.61 & 0.60 & 1.75 \\
\hline sd $( \pm)$ & 8.75 & 10.21 & 3.98 & 11.08 & 10.43 & 1.47 & 0.14 & 1.50 \\
\hline
\end{tabular}




\section{Discussion}

\section{Nitrogen isotopes}

Nitrogen isotopes can provide information on food webs, based on the stepwise enrichment of ${ }^{15} \mathrm{~N} /{ }^{14} \mathrm{~N}$ ratios with increasing trophic level. This is caused by the preferential elimination of ${ }^{14} \mathrm{~N}$ in urine and excretion products and the resulting enrichment of ${ }^{15} \mathrm{~N}$ in tissues and faeces (Miyake and Wada 1967; Steele and Daniel 1978; Checkley and Entzeroth 1985). The absolute values ultimately depend on the isotopic composition of the trophic base of the ecosystem. Here, we assume that this is sPOM, since no evidence has been found for hydrocarbon seepage at the sampled sites (Masson et al. 2003; Kiriakoulakis et al. 2004 submitted). $\delta^{15} \mathrm{~N}$ of sPOM from the three deep-water sites studied here (Darwin, Hovland and Belgica Mounds) shows some variability, but the sites are not significantly different. Interannual variability at the Belgica Mounds area (see Table 2) probably reflects differing nitrogen fractionation during phytoplankton production in the overlying waters (see below). The mean isotopic composition of nitrogen in both coral species studied here is about 2.5-3.5\% heavier than that in sPOM. Many studies have shown that higher trophic levels of an ecosystem show a nitrogen isotopic enrichment of about 3-3.5 \%o, (e.g., DeNiro and Epstein 1981; Miniwaga and Wada 1984; Schoeninger and DeNiro 1984; Toda and Wada 1990; Cabana and Rasmussen 1994). Thus a simplistic view would be that the DWCs feed on sPOM. However, in deep-sea benthic ecosystems, which are usually food limited, the paucity of nitrogen is likely to lead to rather limited isotopic fractionation through benthic respiration. Indeed, Iken et al. (2001) showed that in a deep-sea benthic setting in the NE Atlantic Ocean (Porcupine Abyssal Plain), there is significant overlap in nitrogen isotopic values between trophic levels, reducing the "typical" $3 \%$ stepwise enrichment and indicating overlap in food sources. Therefore, additional information is needed for more secure conclusions regarding the trophic position of the corals (see below).

$\delta^{15} \mathrm{~N}$ values in $L$. pertusa showed variability between the sites, being heavier in the Norwegian fjord and shelf (see Table 1). Between-reef isotopic variability in $\delta^{15} \mathrm{~N}$ and $\delta^{13} \mathrm{C}$ has been shown before in shallow-water coral tissue (Heikoop et al. 2000a) and this was attributed to varying environmental factors such as temperature, light intensity, eutrophication, and terrestrial inputs, which affect nitrogen fractionation during photosynthesis. Subsequent incorporation of photosynthetic nitrogen into the coral tissue, either via autotrophy or heterotrophy, could then reflect or even enhance this variability. Similar "coupling" of regional variation in $\delta^{15} \mathrm{~N}$ values of phytoplankton with that in DWCs may also occur, if phytoplankton detritus, which forms an important part of sPOM (Kiriakoulakis et al. 2004), stays relatively unaltered (i.e., "fresh") during transport to the sea bed. The regional variation in $\delta^{15} \mathrm{~N}$ values of the corals may therefore ultimately reflect the nitrogen dynamics of the surface waters. Anthropogenic inputs have also been shown to shift the nitrogen isotopic values of shallow-water coral reefs towards heavier values (Heikoop et al. 2000b; Risk and Erdmann 2000). This could also be a plausible explanation of heavier values in Norwegian corals in this study because they are located very close to land (Fig. 1) and in relatively shallow waters (Table 1). 
$\delta^{15} \mathrm{~N}$ values in $M$. oculata also show some variability (see Table 1), but they are lighter than those of L. pertusa by about 0.6-0.8\%o at the Darwin and Belgica Mounds. These results are preliminary, but could indicate an overlap in feeding, perhaps with a different degree of selection. Iken et al. (2001) showed that suspension feeders (cnidarians) at the Porcupine Abyssal Plain exhibited a wide trophic spectrum, feeding both on particulate material and live prey.

\section{Total lipids}

A recent study of sPOM at the benthic boundary layer (BBL) of British and Irish waters revealed that there is fresh (i.e., lipid-rich) sPOM supply at all sites considered here. Nevertheless, there is some variability which may be related to the distinct oceanographic regime of each site (Kiriakoulakis et al. submitted).

The total lipid composition in both coral species is dominated by fatty acids, of which PUFAs and MUFAs comprise significant, although different and variable, proportions (see Table 4). PUFAs in the marine environment are usually thought to derive mainly from phytoplankton (e.g., Parrish et al. 2000), although they are often found in other marine organisms, including herbivorous zooplankton (Corner et al. 1986 and references therein) and deep-sea bacteria (DeLong and Yayanos 1985; Jøstensen and Landfald 1997; Fang et al. 2000). The main source of PUFAs in the phytoplankton are diatoms which biosynthesise mostly $\mathrm{C}_{20: 5}$ (Volkman et al. 1989), and dinoflagellates which produce more $C_{22: 6}$ (Sargent et al. 1987; Harvey et al. 1988).

The 22:6/20:5 PUFA ratios of both coral species are similar, but significantly different to those of the sPOM samples. This implies that coral PUFAs may have a similar source and that this may not be sPOM. Zooplankton are a potential food source for the corals (see also below), but were not collected at the study sites.

Differences in the biochemistry of the two species may also be important. Recently, Mancini et al. (1999) isolated novel 10-hydroxydocosapolyenoic acids in M. oculata and L. pertusa from Galicia Bank and the Indian Ocean ( $M$. oculata only). These authors pointed out that these fatty acids are considered to be intermediates of the $\mathrm{C}_{20: 4}$ fatty acid cascade in mammals, but rarely are found in marine invertebrates and little is known about their biosynthetic pathways in the marine environment. Such fatty acids were not detected in this study, but the variability in proportions of PUFAs (and MUFAs) of both corals may also be related to environmental, physiological and/or biochemical factors. For example, Oku et al. (2002) showed that the polyps of the shallow-water branching coral Montipora digitata have different lipid distributions according to their position in the branch. Clearly much more detailed work is required (see also Mancini et al. 1999).

Herbivorous and omnivorous mesozooplankton feeding predominantly on phytoplankton contain elevated amounts of MUFAs within the wax ester lipid fraction (Ratnayake and Ackman 1979; Graeve et al. 1994; Albers et al. 1996). Moreover, calanoid copepods, which overwinter at depth and constitute a large proportion of the mesozooplankton community in the N.E. Atlantic (e.g., Heath and Jónasdóttir 1999; Planque and Batten 2000), are currently the only organisms 
known to biosynthesize de novo $\mathrm{C}_{20: 1}$ and $\mathrm{C}_{22: 1}$ fatty acids (MUFAs identified in this study) and alcohols (for a review see Dalsgaard et al. 2003). Thus, MUFAs and their corresponding alcohols are commonly used as mesozooplankton markers. It should be noted that the mean proportion of MUFAs and alcohols (of which $\mathrm{C}_{20: 1}$ and $\mathrm{C}_{22: 1}$ alcohols are dominant) in both DWCs are significantly higher than that in SPOM. This suggests that the corals may acquire these fatty acids from mesozooplankton, supporting the indication from 22:6/20:5 ratio. Similarly, enrichment of MUFAs in L. pertusa (indicated by the lower PUFA/MUFA ratio), relative to $M$. oculata could be attributed to strategies that assimilate more zooplankton tissue, consistent with the heavier $\delta^{15} \mathrm{~N}$ values of L. pertusa. Alternatively, metabolism of these compound classes could be different in the two species.

Proportions of microbial fatty acids were similar in both coral species but lower than those in sPOM. Microbial biomarkers are commonly found in sPOM (e.g., Kiriakoulakis et al. 2001), therefore their presence in the coral tissue is unsurprising, although it is not clear from whether they are dietary or symbiotic. Even so, their usefulness as biomarkers is currently disputed (see discussion in Parrish et al. 2000) and they should be used with caution and in a qualitative rather than quantitative sense in estimating microbial contributions.

\section{Conclusions}

1. Increased abundances of MUFAs and alcohols and different ratios of 22:6/20:5 in DWCs when compared with sPOM implies that they may largely feed on mesozooplankton.

2. The enrichment of MUFAs and ${ }^{15} \mathrm{~N}$ in L. pertusa relative to M. oculata could be attributed to different feeding and/or assimilation/storage strategies of mesozooplankton tissue or to different metabolism in the two coral species.

\section{Acknowledgements}

We are grateful to the Masters and crews of the RRS Discovery 248, FS Poseidon 265 and 292, FS Belgica (2000 and 2001), and L'Atalante CARACOLE for help with the collection of samples. Professor Michael Risk and an anonymous referee provided useful comments on the original manuscript. We thank Drs. Andrew Wheeler, Donal Eardly, Ann Vanreusel, Andres Rüggeberg and Saskia van Gaever for useful discussions. We also thank Peter Ditchfield for the isotopic analyses. This work was carried out in ACES and ECOMOUND projects (EC-funded contracts EVK3-CT1999-00008 and EVK3-CT1999-00013 respectively) under the Framework V programme.

\section{References}

Albers CS, Kattner G, Hagen W (1996) The compositions of wax esters, triacylglycerols and phospholipids in Arctic and Antarctic copepods: evidence of energetic adaptations. Mar Chem 55: 347-358 
Bett BJ (2000) Benthic ecology of the Faeroe-Shetland Channel, Section 4.3.1 in Environmental Surveys of the Seafloor of the UK Atlantic Margin, Atlantic Frontier Environmental Network [CD-ROM, 53 pp, Geotek Limited, Daventry, Northants NN11 $5 \mathrm{EA}, \mathrm{UK}]$

Brassell SC, Eglinton G (1986) Molecular geochemical indicators in sediments. In: Sohn M (ed) Organic Marine Geochemistry, 305. Amer Chem Soc, Washington, DC, pp 10-31

Cabana G, Rasmussen JB (1994) Modelling food chain structure and contaminant bioaccumulation using stable nitrogen isotopes. Nature 372: 255-257

Christie WW (1982) Esterification of fatty-acids in adipose-tissue. J Sci Food Agricult 33: 809-809

Checkley DM, Entzeroth LC (1985) Elemental and isotopic fractionation of carbon and nitrogen by marine, planktonic copepods and implications to the marine nitrogen cycle. J Plankton Res 7: 553-568

Corner EDS, O'Hara SCM, Neal AC, Eglinton G (1986) Copepod faecal pellets and the vertical flux of biolipids. In: Corner EDS, O'Hara SCM (eds) The Biological Chemistry of Marine Copepods. Oxford Sci Publ, pp 260-321

Dalsgaard J, St John M, Kattner G, Muller-Navarra D, Hagen W (2003) Fatty acid trophic markers in the pelagic marine environment. Adv Mar Biol 46: 225-340

DeLong EF, Yayanos AA (1985) Adaptation of the membrane lipids of a deep-sea bacterium to changes in hydrostatic pressure. Science 228: 1101-1103

De Mol B, Van Rensbergen P, Pillen S, Van Herreweghe K, Van Rooij D, McDonnell A, Huvenne V, Ivanov M, Swennen R, Henriet JP (2002) Large deep-water coral banks in the Porcupine Basin, southwest of Ireland. Mar Geol 188: 193-231

De Mol B, Henriet JP, Canals M (2005) Development of coral banks in Porcupine Seabight: do they have Mediterranean ancestors? In: Freiwald A, Roberts JM (eds) Cold-water Corals and Ecosystems. Springer, Berlin Heidelberg, pp 515-533

DeNiro MJ, Epstein S (1981) Influence of diet on the distribution of nitrogen isotopes in animals. Geochim Cosmochim Acta 45: 341-351

Fang J, Barcelona MJ, Nogi Y, Kato K (2000) Biochemical implications and geochemical significance of novel phospholipids of the extremely barophilic bacteria from the Marianas Trench at 11,000 m. Deep-Sea Res I 47: 1173-1182

Freiwald A (2002) Reef-forming cold-water corals. In: Wefer G, Billett D, Hebbeln D, Jørgensen BB, Schlüter M, van Weering T (eds) Ocean Margin Systems. Springer, Berlin Heidelberg, pp 365-385

Freiwald A, Wilson JB. Henrich R (1999) Grounding Pleistocene icebergs shape recent deepwater coral reefs. Sediment Geol 125: 1-8

Freiwald A, Hühnerbach V, Lindberg B, Wilson JB, Campbell J (2002) The Sula Reef Complex, Norwegian shelf. Facies 47: 179-200

Graeve M, Hagen W, Kattner G (1994) Herbivorous or omnivorous - on the significance of lipid compositions as trophic markers in Antarctic copepods. Deep-Sea Res 41: 915924

Harland AD, Navarro JC, Spencer Davies P, Fixter LM (1993) Lipids of some Caribbean and Red Sea corals: total lipid, wax esters, triglycerides and fatty acids. Mar Biol 117: 113-7

Harvey HR, Bradshaw SA, Ohara SCM, Eglinton G, Corner (1988) Lipid composition of the marine dinoflagellate Scrippsiella trochoidea. Phytochem 27: 1723-1729

Heath MR, Jónasdóttir SH (1999) Distribution and abundance of overwintering Calanus finmarchicus in the Faeroe-Shetland channel. Fish Oceanogr 8 (Suppl 1): 40-60 
Heikoop JM, Dunn JJ, Risk MJ, Tomascik T, Schwarcz HP, Sandeman IM, Sammarco PW (2000a) $\delta^{15} \mathrm{~N}$ and $\delta^{13} \mathrm{C}$ of coral tissue show significant inter-reef variation. Coral Reefs 19: $189-193$

Heikoop JM, Risk MJ, Lazier AV, Edinger EN, Jompa J, Limmon GV, Dunn JJ, Browne DR, Schwarcz HP (2000b) Nitrogen-15 signals of anthropogenic nutrient loading in reef corals. Mar Pollut Bull 40: 628-636

Heikoop JM, Hickmott DD, Risk MJ, Shearer CK, Atudorei V (2002) Potential climate signals from the deep-sea gorgonian coral Primnoa resedaeformis. Hydrobiologia 471: 117-124

Henriet JP, De Mol B, Pillen S, Vanneste M, Van Rooij D, Versteeg W, Croker PF, Shannon PM, Unnithan V, Bouriak S, Chachkine P (1998) Gas hydrate crystals may help build reefs. Nature 391: 648-649

Hesslein RH, Capel MJ, Fox DE, Hallard KA (1991) Stable isotopes of sulphur, carbon, and nitrogen as indicators o trophic level and fish migration in the Lower Mackenzie Rive Basin, Canada. Canad J Fish Aquat Sci 4: 2258-2265

Hovland M, Croker PF, Martin M (1994) Fault-associated seabed mounds (carbonate knolls) off western Ireland and North-West Australia. Mar Petrol Geol 11: 232-246

Hovland M, Thomsen E (1997) Cold-water corals - are they hydrocarbon seep related? Mar Geol 137: 159-164

Huvenne VA, Blondel IP, Henriet JP (2002) Textural analyses of sidescan sonar imagery from two mound provinces in the Porcupine Seabight. Mar Geol 189: 323-341

Iken K, Brey T, Wand U, Voigt J, Junghans P (2001) Food web structure of the benthic community at the Porcupine Abyssal Plain (NE Atlantic): a stable isotope analysis. Progr Oceanogr 50: 383-405

Jøstensen J, Landfald B (1997) High prevalence of polyunsaturated fatty acid producing bacteria in Arctic invertebrates. FEMS Microbiol Lett 151: 95-101

Kenyon NH, Ivanov MK, Akmetzhanov AM (1998) Cold-water carbonate mounds and sediment transport on the Northeast Atlantic margin. IOC Tech Ser Paris UNESCO 52, $179 \mathrm{pp}$

Kenyon NH, Akmetzhanov AM, Wheeler AJ, van Weering TCE, de Haas H, Ivanov, MK (2003) Giant carbonate mud mounds in the southern Rockall Trough. Mar Geol 195: 5-30

Kidd KA, Schindler DW, Hesslein RH, Muir DCG (1995) Correlation between stable isotope ratios and concentrations of organochlorines in biota from a freshwater food web. Sci Total Environ 161: 381-390

Kiriakoulakis K, Stutt E, Rowland SJ, Vangriesheim A, Lampitt RS, Wolff GA (2001) Controls on the organic chemical composition of settling particles in the Northeast Atlantic Ocean. Progr Oceanogr 50: 65-87

Kiriakoulakis K, White M, Bett BJ, Wolff GA (2004) Organic biogeochemistry of the Darwin Mounds, a deep-water coral ecosystem, of the NE Atlantic. Deep-Sea Res I 51: 19371954

Kiriakoulakis K, Fisher E, Freiwald A, White M, Wolff GA (submitted) Biogeochemistry of deep-water coral/mound systems at the NW European Continental Margin. Int J Earth Sci

Kling GW, Fry B, O'Brien WJ (1992) Stable isotopes and planktonic trophic structure in arctic lakes. Ecology 73: 561-566

Latyshev NA, Naumenko NV, Svetashev VI, Latypov YY (1991) Fatty acids of reef-building corals. Mar Ecol Progr Ser 76: 295-301 
Mancini I, Guerriero A, Guella G, Bakken T, Zibrowius H, Pietra F (1999) Novel 10hydroxydocosapolyenoic acids from deep-water scleractinian corals. Helvet Chim Acta 82: 677-684

Masson DG, Bett BJ, Billett DSM, Jacobs CL, Wheeler AJ, Wynn RB (2003) The origin of deep-water, coral-topped mounds in the northern Rockall Trough, Northeast Atlantic. Mar Geol 194: 159-180

Meyers PA (1979) Polyunsaturated fatty acids in coral: indicators of nutritional sources. Mar Biol Lett 1979 1: 69-75

Miniwaga M, Wada E (1984) Stepwise enrichment of $\mathrm{N}$ along food chains: further evidence and the relation between $\delta^{15} \mathrm{~N}$ and animal age. Geochim Cosmochim Acta 48: 11351140

Miyake Y, Wada E (1967) The abundance ratio of ${ }^{15} \mathrm{~N} /{ }^{14} \mathrm{~N}$ in marine environments. Records of Ocean Works of Japan 9: 32-53

Mortensen PB (2001) Aquarium observations on the deep-water coral Lophelia pertusa (L., 1758) (Scleractinia) and selected associated invertebrates. Ophelia 54: 83-104

Oku H, Yamashiro H, Onaga K, Iwasaki H, Takara K (2002) Lipid distribution in branching coral Montipora digitata. Fish Sci 68: 517-522

Owens NJP (1987) Natural variations in ${ }^{15} \mathrm{~N}$ in the marine environment. Adv Mar Biol 24: $389-451$

Parrish CC, Abrajano TA, Budge SM, Helleur RJ, Hudson ED, Pulchan K, Ramos C (2000) Lipid and phenolic biomarkers in marine ecosystems: analysis and applications. In: Wangersky P (ed) The Handbook of Environmental Chemistry. Part D. Marine Chemistry. Springer, Berlin Heidelberg, pp 193-223

Peterson BJ, Fry B (1987) Stable isotopes in ecosystem studies. Ann Rev Ecol Systems 18: 293-320

Planque B, Batten SD (2000) Calanus finmarchicus in the North Atlantic: the year of Calanus in the context of interdecadal change. ICES J Mar Sci 57: 1528-1535

Ratnayake WM, Ackman RG (1979) Fatty alcohols in capelin, herring and mackerel oils and muscle lipids. I Fatty alcohol details linking dietary copepod fat with certain fish depot fats. Lipids 14: 795-803

Risk MJ, Erdmann MV (2000) Isotopic composition of nitrogen in stomatopod (Crustacea) tissues as an indicator of human sewage impacts on Indonesian coral reefs. Mar Pollut Bull 40: 50-58

Rogers AD (1999) The biology of Lophelia pertusa (LINNAEUS 1758) and other deep-water reef-forming corals and impacts from human activities. Int Rev Hydrobiol 84: 315-406

Sargent JR, Parkes RJ, Mueller-Harvey I, Henderson RJ (1987) Lipid biomarkers in marine ecology. In: Sleigh MA (ed) Microbes in the Sea. Wiley and Sons, New York, pp 119138

Schoeninger MJ, DeNiro MJ (1984) Nitrogen and carbon isotopic composition of bone collagen from marine and terrestrial animals. Geochim Cosmochim Acta 48: 625-639

Steele KW, Daniel RM (1978) Fractionation of nitrogen isotopes by animals: a further complication to the use of variations in the natural abundance of ${ }^{15} \mathrm{~N}$ for tracer studies. J Agricult Sci 90: 7-9

Toda H, Wada E (1990) Use of ${ }^{15} \mathrm{~N} /{ }^{14} \mathrm{~N}$ ratios to evaluate the food source of the mysid, Neomysis intermedia Czerniawsky, in a eutrophic lake in Japan. Hydrobiologia 194: 85-90

Wilson JB (1979). The distribution of the coral Lophelia pertusa (L) [L. prolifera (Pallas)] in the north-east Altantic. J Mar Biol Ass UK 59: 149-164 
Van Rooij D, De Mol B, Huvenne V, Ivanov M, Henriet JP (2003) Seismic evidence of current-controlled sedimentation in the Belgica mound province, upper Porcupine slope, southwest of Ireland. Mar Geol 195: 31-53

Volkman, JK, Jeffrey SW, Nichols PD, Rogers GI, Garland CD (1989) Fatty-acid and lipidcomposition of 10 species of microalgae used in mariculture. J Exp Mar Biol Ecol 128: 219-240

Yamashiro HH, Oku H, Higa H, Chinen I, Sakai K (1999) Composition of lipids, fatty acids and sterols in Okinawan corals. Comp Biochem Phys B 122: 397-407 
